cancer. ${ }^{12}$ The incidence in the Western world may be lower still. In the United States, only 8 of $28(28 \%)$ patients with the disease were found to have the fetal protein, ${ }^{13}$ and in another study $40 \%$ of sera gave positive results. ${ }^{14}$ In London only 5 out of 17 Britons with primary liver cancer showed the fetal protein in their serum, whereas 5 out of 8 from West Africa and 4 out of 10 from other countries were positive. ${ }^{15}$ Yet the histological features of the tumours from various parts of the world were similar. The level of fetal protein was poorly correlated with liver size, and serial estimations showed little rise in the amount of it as time passed. ${ }^{11}$ More study is required of serum fetal proteins in the various forms of hepatic tumours encountered in different parts of the world. The introduction of more sensitive methods of assay may increase the percentage of patients giving positive results, and quantitation may allow more accurate correlation of concentration with size of tumour, histological type, rate of growth, and clinical course.

These geographic differences might be linked with aetiological factors. In the tropics in recent years it has been suggested that primary liver cancer may be associated with poisoning by various mycotoxins, particularly aflatoxin B. This carcinogen was first described in 1960, when it was responsible for an outbreak of jaundice in turkeys and ducklings in Britain and on the Continent. ${ }^{16}$ The common causal factor was traced to the animals having fed on ground-nut meal prepared from nuts shipped from Brazil. The active compound was extracted from the nuts and found to be an aflatoxin produced by a contaminating mould, Aspergillus flavus. This and similar toxic moulds can readily contaminate food such as ground-nuts or grain when they are stored in tropical conditions, and aflatoxin has in fact been detected in $40 \%$ of Ugandan foods. ${ }^{17}$ Moreover, Ugandan tribes with the lowest socio-economic status, and so the greatest chance of eating mouldy foods, have the highest incidence of liver-cell carcinoma. ${ }^{17}$ Clearly many more studies must be made of the food consumed by populations which seem particularly at risk of developing

1 Doll, R., Payne, P., and Waterhouse, J., (eds.), Cancer Incidence in Five Continents. Heidelberg, International Union against Cancer and Springer Verlag. 1966.

2 Steiner, P. E. Cancer, 1960, 13, 1085

3 Alpert, M. E., Hutt, M. S. R., and Davidson, C. S., American fournal of Medicine, 1969, 46, 794.

Steiner, P. E., Acta; Unio Internationalis Contra Cancrum, 1961, 17, 798.

5 Scheuer, P. I., Liver Biopsy Interpretation, p. 60. London, Baillière, Tindall and Cassell. 1968.

${ }^{6}$ Gitlin, D., and Boesman, M., Fournal of Clinical Investigation, 1966 45, 1826

7 Adinolfi, M., and Gardner, B., fournal of Developmental Medicine and Child Neurology, 1967, 9, 609.

3 Abelev, G. I., Cancer Research, 1968, 28, 1344

9 Tatarinov, Y. S., Federation Proceedings, 1966, 25, T 344 (translation)

10 Uriel, J.. Pathologie et Biologie, in press.

11 Purves, L. R., Macnab, M., and Bersohn, I., South African Medical Fournal, 1968, 42, 1138.

12 Alpert, M. E., Uriel, J., and de Nechaud, B., New England fournal of Medicine, 1968, 278, 984.

13 Alpert, M. E., Clinical Research, 1969, 17, 461.

14 Hull, E. W., Moertel, G., and Carbone, P. P., Clinical Research, 1969, 17, 403 .

15 Foli, A. K., Sherlock, S., and Adinolfi, M., Lancet, 1969, 2, 1267.

6 Sargeant, K., Sheridan, A., O'Kelly, J., and Carnaghan, R. B. A., Nature, 1961, 192, 1096.

17 Alpert, M. E., Wogan, G., and Davidson. C. S., Gastroenterology, 1968 , 54, 149.

18 Newberne, P. M., and Butler, W. H., Cancer Research, 1969, 29, 236.

19 Cuthbertson, W. F. J., Lauresen, A. C., and Pratt, D. A. H., British Fournal of Nutrition, 1967, 21, 893.

Sherlock, S., Diseases of the Liver and Biliary System, 4th ed., p. 335 Oxford. Blackwells Scientific Publications. 1968.

21 Blumberg, B. S., Sutnick, A. I., and London, W. T., foumal of the American Medical Association, 1969, 207, 1895.

22 British Medical fournal, 1969, 2, 645.

23 Wright, R., McCollum, R. W., and Klatskin, G., Lancet, 1969, 2, 117

24 Hou, P. C., Fournal of Pathology and Bacteriology, 1956, 72, 239. this tumour. Simple screening tests performed on urine samples for aflatoxin and other mycotoxins, and capable of field use, are urgently required.

Aflatoxin is h:ghly carcinogenic to certain species, particularly to the rainbow trout, to the mouse, and, on a long-term basis, to the guinea pig. But species vary in their susceptibility. ${ }^{18}$ For instance, it does not appear to be carcinogenic to the monkey. ${ }^{19}$ But this is no certain indication that tumours will not develop in primates, or indeed in man, under different conditions and particularly with long exposure. Primary liver cancer in the tropics is marked by a high incidence of fetal protein in the serum. This is not so in the aflatoxin-induced experimental hepatic tumours. This may be taken as some, though only circumstantial, evidence that aflatoxin is not the whole answer to the problem of primary liver cancer in the tropics.

The relationship of primary liver cancer to a preceding attack of acute virus hepatitis would presumably be through an intervening post-hepatitis cirrhosis. Follow-up studies of recent large epidemics of virus hepatitis indicate that in fact cirrhosis is an extremely rare complication of this common infectious disease. ${ }^{20}$ Moreover, much of the cirrhosis of the tropics is unrelated to hepatitis. But any relationship between primary hepatic carcinoma and virus hepatitis remains uncertain. Recently it has been recognized that petients with acute virus hepatitis often have an antigen in their serum (Australia antigen or hepatitis-associated antigen $^{2122}$, and in some instances this persists. ${ }^{23}$ The frequency of hepatitis-associated viruses in patients with livercell carcinoma has not been determined, and knowledge of the world-wide incidence of the antigen in various populations is incomplete. Data on these questions are immediate research objectives and should be obtained in the next few years.

The primary cholangio-cellular carcinoma encountered in the Far East and particularly well described from Hong $\mathrm{Kong}^{24}$ also has geographical variations. It is associated with infestation of the bile ducts by the Chinese liver fluke, Clonorchis sinensis. The tumour apparently arises in direct relation to flukes residing in the small intrahepatic bile ducts. A metaplasia of the mucous glands precedes the cholangio-cellular carcinoma. Further work is needed to determine the possible nature of any carcinogen contained in the fluke.

\section{Paralysed Hemidiaphragm and Shingles}

A paralysed hemidiaphragm may be suspected when a radiograph of the chest shows the leaf to be abnormally raised. Confirmation of the paralysis is obtained by fluoroscopy. The paralysed side moves paradoxically during the act of sniffing - that is, it moves passively upwards as the opposite leaf descends during contraction and displaces the abdominal contents. The cause of the paralysis is usually obvious. It may be, for example, bronchial carcinoma with extension to the mediastinum; trauma, including surgical operation; or an infection such as poliomyelitis. Occasionally phrenic paresis is discovered without apparent cause, possibly in a patient who complains of breathlessness or who has undergone routine mass miniature radiography.

The virus of herpes zoster typically attacks a single spinal 
nerve, giving a painful, unilateral vesicular eruption in the distribution of the affected nerve. Pathological changes occur predominantly in the dorsal root and its ganglion, but often they extend to the adjacent posterior, lateral, and anterior horns of the grey matter. ${ }^{1}$ Rarely they reach the upper motor neurones, the brain, and meninges. ${ }^{2}$ Hence motor weaknesses associated with shingles can be adequately accounted for. They are most likely to be recognized when cranial nerves are affected, and are indeed obvious in the Ramsey-Hunt syndrome (facial palsy and lesions of the external auditory meatus) and the oculomotor paresis which sometimes accompanies zoster of the ophthalmic devision of the trigeminal nerve.

J. H. Taterka and M. E. O'Sullivan, ${ }^{3}$ reviewing 42 cases of spinal shingles with muscular involvement from the world literature, found that in 19 the upper limb was affected, in 17 the trunk, and in 6 the lower limb. Almost invariably the rash and the paresis had the same segmental distribution and they developed simultaneously, the most commonly affected muscle being the deltoid. But the attack rate of the midcervical segments supplying the phrenic nerve seems to be rather low, being observed in only 14 of 192 cases in one report $^{4}$ and 30 of 392 cases in another. ${ }^{5}$ S. L. Halpern and A. H. Covner ${ }^{6}$ are credited with having first described a patient with both shingles and phrenic paralysis. J. P. Anderson and E. E. Keal ${ }^{7}$ have recently published four more case reports and could only find 11 others. In the majority the paralysis persisted for as long as it was observed.

While the simultaneous development of shingles of a mid-cervical spinal nerve and phrenic paresis may now be accepted as a clinical syndrome, the story is not yet complete. Variation in the extent of the lesion in the motor grey matter of the spinal cord allows of partial paralysis of the diaphragm which may be difficult to detect fluoroscopically. The phrenic nerve derives its fibres from the third, fourth, and fifth cervical nerves, and impairment of one of these may not be clinically detectable. (In poliomyelitis thorough investigation has shown that not all the anterior horn cells are essential for apparently normal function.) Another aspect of the disease which calls for further study is the possibility that the virus of herpes zoster may infect without causing a rash. R. S. Aitken and R. T. Brain ${ }^{8}$ found positive complement-fixation tests for zoster in 4 of 32 patients with "idiopathic" facial palsy. These imponderables imply that in future we should look a little more critically at patients who present with either cervical shingles or an unexplained phrenic paralysis.

\section{Exploring the Red Cell}

The detailed structure of cells can be visualized directly by optical microscopy or indirectly and at much higher magnification by transmission electron-microscopy. Optical microscopy is restricted by its lack of resolving power for

\footnotetext{
1 Greenfield, J. G., Blackwood, W., McMenemy, W. H., Meyer, A., and Norman, R. M., Neuropathology, pp. 185-7. London, Arnold. 1958. Brain, W. R., British Medical fournal, 1931, 1, 81.

Taterka, J. H., and O'Sullivan, M. E., Fournal of the American Medical Association, 1943, 122, 737. 4 Hope-Simpson, R. E., Proceedings of the Royal Society of Medicine,

5 Head, H., Brain, 1900, 23, 353.

6 Halpern, S. L., and Covner, A. H., Archives of Internal Medicine, 1949, 84, 907.

Anderson, J. P., and Keal, E. E., British Fournal of Diseases of the Chest, 1969, 63, 222

8 Aitken, R. S., and Brain, R. T., Lancet, 1933, 1, 19.
}

fine detail, while electron-microscopy, though providing much higher resolution, is dependent on indirect and more complex methods such as shadowing with heavy metals, negative staining, and thin sections.

In the last few years a new device, the scanning or stereoscan electron-microscope, has been applied to the study of the fine structure of cells. This instrument can be used at the magnification of light microscopy, since the depth of focus is much greater than that of conventional light or electron-microscopes. The resulting image of cells, which represents a magnification of up to thirty thousand, is three-dimensional and remarkably sharp. Scanning electronmicroscopy has been applied to biological materials ${ }^{1-3}$ and to metal surfaces. ${ }^{2}$ More recently it has been used for studying human blood cells, especially red cells ${ }^{4}$ and plasma cells. 5

The stereoscan electron-microscope employs an electron beam which moves over the specimen, the emerging electrons then being collected and amplified in a photo-multiplier. The resulting signal controls the brightness of a spot from a cathode-ray tube which moves over a screen in correspondence with the movement of the electron beam over the specimen and produces an image of the object under examination. For optimum results the surface of the specimen must be coated with an electrically conducting thin metal. The resolution is about $200 \AA$, and stereoscan electron-microscopy thus bridges a gap between optical microscopes and conventional transmission electron-microscopes.

The scanning electron-microscope is particularly suitable for examining the surfaces and shapes of cells, but until recently it has not been able to give a view of the inner structure of the surface membrane or of the internal structure of the cell. It has now been shown ${ }^{6}$ that the surface of red cells can be removed in layers by applying the technique of ion-bombardment etching. The surface under examination is bombarded with ions emanating from a glow discharge in a gas (hydrogen, oxygen, argon, or water vapour) under pressure. Each ion striking the surface knocks off an atom and in this way the surface is etched. Ion etching can turn differences in the density and composition of specimens into topographical differences, which can be readily observed in the scanning electron-microscope. It has been used in examining the structure of metals, inorganic compounds, glass, and polymers. Until recently its application to biological materials was restricted to hard substances such as teeth and bone, but ion etching has now been applied to soft biological materials such as red cells. ${ }^{6}$

In accordance with variation in the degree of the etching it has been possible to see an organized structure in the red cell, both at different levels in the membrane and also within the cell itself. By this means the red-cell membrane appears to be heterogenous, showing etch-resistant areas dispersed over the surface. The membrane also shows indentations or pores especially prominent in the concave area of the cell,

1 Boyde, A., and Stewart, A. D. G., Nature, 1963, 198, 1102. Oatley, C. W., Nixon, W. C., and Pease, R. F. W., Advances in Electronics and Electron Physics, vol. 21, p. 18i. New York, Academic Press. 1965.

3 Boyde, A., and Quilliam, T. A., Medical and Biological Illustration, $1966,16,116$.

Salsbury, A. J., and Clarke, J. A., fournal of Clinical Pathology, 1967. Clarke, J. 1968, 18, 165.

6 Lewis, S. M., Osborn, J. S., and Stuart, P. R., Nature, 1968, 220, 614

7 Stuart, P. R., Osborn, J. S., and Lewis, S. M., Medical and Biological Illustration, 1969, 19, 202

8 Lehmann, H., and Huntsman, R. G., in Functions of the Blood, ed. Macfarlane, R. G., and Robb-Smith, A. H. T., p. 73. Oxford, Blackwell Scientific Publications. 1961. 